\title{
Zinc Oxide Nanoparticles: The Hidden Danger
}

\author{
Mona A. EI Shemy ${ }^{1}$, Naglaa Ibrahim Azab ${ }^{2, ~ *, ~ R a b a b ~ F a w z y ~ S a l i m ² ~}$ \\ ${ }^{1}$ Department of Clinical Pathology, Faculty of Veterinary Medicine, Benha University, Benha, Egypt \\ ${ }^{2}$ Department of Medical Biochemistry, Faculty of Medicine, Benha University, Benha, Egypt
}

\section{Email address:}

naglaa1270@yahoo.com (N. I. Azab),naglaa.azab@fmed.bu.edu.eg (N. I. Azab), ehabfawzi2002@yahoo.com (M. A. El Shemy), tohamy24@yahoo.com (R. F. Salim)

${ }^{*}$ Corresponding author

\section{To cite this article:}

Mona A. El Shemy, Naglaa Ibrahim Azab, Rabab Fawzy Salim. Zinc Oxide Nanoparticles: The Hidden Danger. International Journal of Biochemistry, Biophysics \& Molecular Biology. Vol. 2, No. 1, 2017, pp. 1-9. doi: 10.11648/j.ijbbmb.20170201.11

Received: October 19, 2016; Accepted: November 12, 2016; Published: February 22, 2016

\begin{abstract}
Zinc oxide nanoparticles (ZnO-NPs) are used in many industries and medications, increasing the exposure to $\mathrm{ZnO}-\mathrm{NPs}$ that may have harmful side effects. So, we studied the hepatotoxic effect of ZnO-NPs and explored the role of vitamin $\mathrm{E}$ in the reduction of their toxic effects. Forty male albino rats, divided into four groups (10 rats per group) were included in the study; control group, ZnO-NPs intoxicated group, vitamin E control group and vitamin E protected ZnO-NPs intoxicated group. ZnO-NPs were given in a dose of $400 \mathrm{mg} / \mathrm{kg}$ body weight for seven days. Vitamin E was given in a dose of $100 \mathrm{mg} / \mathrm{kg}$ body weight for four weeks. Our results showed that ZnO-NPs induced liver damage indicated by significant increase of serum ALT and AST and significant decrease of serum albumin and total protein levels. Moreover, ZnO-NPs induced oxidative stress in the liver suggested by significant elevation of malondialdehyde level and significant reduction of reduced glutathione level, glutathione peroxidase activity and glutathione peroxidase-1 expression in liver homogenate. Furthermore, ZnO-NPs caused significant increase in the serum pro-inflammatory biomarker, tumor necrosis factor alpha (TNF- $\alpha$ ). On the other hand, vitamin E alleviated the liver damage, oxidative stress and the elevated serum TNF- $\alpha$ induced by $\mathrm{ZnO}-\mathrm{NPs}$.
\end{abstract}

Keywords: Zinc Oxide Nanoparticles (ZnO-NPs), Vitamin E, Liver, Oxidative Stress,

Tumor Necrosis Factor Alpha (TNF- $\alpha$ )

\section{Introduction}

Nanoparticles (NPs) possess different physical and chemical properties, making them extremely important for and to be used on a wide scale of biological, medical and industrial applications [46]. Zinc oxide nanoparticles ( $\mathrm{ZnO}-\mathrm{NPs}$ ) are widely used in industrial and costumer products including sunscreens, toothpastes, paint formulations, as food additive and as photocatalyst for pollution control [48]. Therefore, the utilization and release of $\mathrm{ZnO}-\mathrm{NPs}$ to the environment are increasing leading to the appearance of the adverse effects on human and animal health which may be due to its cumulative effect. $[9,46]$.

The small particle size of NPs including ZnO-NPs creates large surface area per unit mass, thus increasing surface reactivity of NPs in the cells and their ability to produce reactive oxygen species (ROS) [13]. Therefore, NPs may cause more inflammation than larger particles of the same materials at the same dose [60].
NPs can enter the human body through different routes as ingestion and inhalation [13]. Due to their small size, NPs can translocate through epithelial and endothelial cells into the circulatory and lymphatic systems to reach body tissues and organs as liver, kidneys, heart, spleen and bone marrow where they induce cell damage by oxidative stress and/or organelle injury $[2,45,61]$.

Oxidative stress and ROS mediated damage are one of the most harmful toxic effects of NPs. Oxidative stress occurs when the generation of ROS from NPs in the body exceeds the ability of the body to neutralize and eliminate them [33].

ROS describe a number of highly reactive molecules derived from the metabolism of molecular oxygen such as superoxide radicals, hydroxyl radicals, hydrogen peroxide, nitric oxide, lipid alkoxyl and peroxyl radicals. They react with macromolecules (lipids, proteins, DNA) within the cell, with one of the most frequent effects being lipid peroxidation that is oxidation of the polyunsaturated fatty acids that largely comprise the cell 
membranes. Lipid peroxidation is commonly quantified in research studies by measuring the accumulation of the byproducts that result from this process as malondialdehyde (MDA) [23].

Glutathione peroxidase (GPx) is one of the important antioxidant enzymes. It reduces free hydrogen peroxides and lipid hydroperoxides in order to protect the cells from oxidative damage [40]. GPx requires reduced glutathione (GSH) for its action in conversion of hydrogen peroxide to water. Also GSH has direct antioxidant activity, by donation of hydrogen ions to repair damaged DNA [32]. GSH acts not only as a reducing agent and a major antioxidant within the cells, but also as a mediator of several other physiologic reactions as metabolism of xenobiotics and cellular signaling (cell-cycle regulation, cellular proliferation and apoptosis) [35].

Several isozymes of GPx are encoded by different genes. They vary in cellular location and substrate specificity. Glutathione peroxidase-1 (GPx-1), the most abundant one is present in the cytoplasm of nearly all mammalian tissues, and is thought to be the main cellular scavenger of $\mathrm{H} 2 \mathrm{O} 2$ [39]. Also it can metabolize a range of organic peroxides, including cholesterol and long-chain fatty acid peroxides. It is very specific for glutathione as reducing substrate [6].

$\mathrm{ZnO}-\mathrm{NPs}$ increase the level of hydrogen peroxide and hydroxyl radicals and also decrease the level of glutathione. Large amounts of ROS are generated even with using a small amount of ZnO-NPs [9].

Tumor necrosis factor alpha (TNF- $\alpha)$ is considered a proinflammatory cytokine that has an important role in the inflammatory response. Its production is induced by multiple factors as viruses, parasites, other cytokines, and endotoxins. TNF- $\alpha$ action is mediated by two cell surface receptors, TNF- $\alpha$ receptor 1 and TNF- $\alpha$ receptor 2 [27]. TNF- $\alpha$ receptor 1 is widely distributed, while TNF- $\alpha$ receptor 2 is limited to cells of hematopoietic origins. TNF- $\alpha$ receptor 1 produces most of the TNF- $\alpha$ cellular responses, including activation of nuclear factor kappa beta $(\mathrm{NF} \kappa \mathrm{B})$ and apoptosis $[22,28]$. Serum TNF- $\alpha$ was reported to increase secondary to ZnO-NPs toxicity [62].

Vitamin $\mathrm{E}$ is an effective antioxidant and anti-inflammatory agent that prevents the propagation of oxidative stress, especially in biological membranes in animals and humans [2].

This study was designed to investigate the hepatotoxic effect of $\mathrm{ZnO}-\mathrm{NPs}$, the role of oxidative stress in this effect, and to evaluate the antioxidant and hepatoprotective effects of vitamin $\mathrm{E}$ in $\mathrm{ZnO}-\mathrm{NPs}$ induced hepatotoxicity. It is to be emphasized that the GPx-1 gene expression and its relation to GPx activity in response to vitamin $\mathrm{E}$ and/or $\mathrm{ZnO}-\mathrm{NPs}$ administration in experimental animals were not evaluated before.

\section{Materials and Methods}

\subsection{Animals and Grouping}

Forty male albino rats with average body weight $125 \mathrm{gm}$ were used in this study. Rats were obtained from United Co. for Chemical and medical preparation, Cairo, Egypt. Animals were housed in separate metal cages. Fresh and clean drinking water was supplied ad libtium. The animals were left for 15 days for acclimatization before the beginning of the experiment. Rats were kept at constant nutritional and environmental condition throughout the period of experiment. Animal experiments were performed with compliance of the local ethical committee.

The rats were divided into four groups (10 rats per group). Group I was used as a control. Group II was the ZnO-NPs intoxicated group that was administered 400mg ZnO-NPs / $\mathrm{kg}$ body weight for seven days. Group III was the vitamin E control group and was administered 100mg vitamin E / kg body weight for four weeks. Group IV was vitamin E protected $\mathrm{ZnO}-\mathrm{NPs}$ intoxicated group in which vitamin $\mathrm{E}$ was given in a dose of $100 \mathrm{mg} / \mathrm{kg}$ body weight as a protection for three weeks before administration of ZnO-NPs then vitamin $\mathrm{E}$ was continued for another one week in combination with $\mathrm{ZnO}-\mathrm{NPs}$, which was given in a dose of $400 \mathrm{mg} / \mathrm{kg}$ body weight.

$\mathrm{ZnO}$ nanopowder; product number 544906, and the oily preparation of vitamin E provided by SIGMA Aldrich-USA, were given orally using a stomach tube with the above mentioned doses according to Somayeh and Mohammad (2014) [50] and Al-Rasheed et al. (2014) [2] respectively . $\mathrm{ZnO}$ nanopowder had a particle size of $<100 \mathrm{~nm}$ and a Specific Surface Area of $15-25 \mathrm{~m}^{2} / \mathrm{g}$.

\subsection{Biochemical Serum Assay}

Blood samples were obtained from the retro-orbital venous plexus, after that blood was collected and centrifuged to separate serum for biochemical analysis of (ALT, AST, total proteins, albumin and TNF- $\alpha$ ).

\subsubsection{Serum ALT, AST, Total Proteins and Albumin Levels Estimation}

Serum ALT, AST, total proteins and albumin levels were estimated using kits supplied by Diamond Diagnostics, Egypt according to the manufacturer instructions.

\subsubsection{Serum TNF- $a$ Level Estimation}

Serum TNF- $\alpha$ level was measured using Quantikine ${ }^{\circledR}$ ELISA Rat TNF- $\alpha$ Immunoassay kit manufactured by R\&D Systems, Inc,USA.

\subsection{Biochemical Assay and Gene Expression Analysis of the Liver Tissue}

The collected Liver specimens after scarification of the rats were divided into two portions; the first was rapidly washed with saline to avoid its drying, weighted and processed for determination of MDA level, GSH level and GPx activity. The second portion was rapidly freezed at $80^{\circ} \mathrm{C}$ till determination of GPx-1 gene expression using real time PCR.

\subsubsection{GSH Concentration Estimation}

GSH concentration was measured in the liver tissue homogenate according to the method described by Beutler et al. (1963) [8]. 


\subsubsection{GPx Activity Determination}

GPx activity in the liver tissue homogenate was determined following the method described by Paglia and Valentine (1967) [42].

\subsubsection{MDA Level Determination}

L-malondialdehyde was determined colorimetrically according to the method described by Ohkawa et al. (1979) [41].

\subsubsection{GPx-1 Gene Expression Analysis}

\section{i. Total RNA Extraction:}

Extraction of total RNA from the liver tissue was performed using Direct-zol ${ }^{\mathrm{TM}}$ RNA MiniPrep kitZymosearch-USA according to the manufacturer instructions. Extracted RNA was evaluated for purity and quantity using nanodrop 1 (Thermoscientific, USA).

ii. Reverse Transcription step:

Total RNA (200ng) in a $20 \mu$ l reaction was reverse transcribed into cDNA using SensiFAST ${ }^{\mathrm{TM}}$ cDNA Synthesis Kit- Biolin, United Kingdom according to the manufacturer instructions.

iii. Real Time PCR for relative quantitation of GPx-1 gene expression:

Real time PCR was performed using SensiFASTTM SYBR No-ROX kit supplied by Bioline, United Kingdom. The $20 \mu \mathrm{L}$ reaction mix contained $10 \mu \mathrm{L} 2 \mathrm{x}$ SensiFAST SYBR No-ROX Mix, $0.8 \mu \mathrm{L}$ of forward primer, $0.8 \mu \mathrm{L}$ of reverse primer, $4 \mu \mathrm{L}$ of $\mathrm{cDNA}$, and $4.4 \mu \mathrm{L}$ RNase-free water. Amplification of GPx-1 and the house keeping gene GAPDH were done in separate PCR tubes. Primers sequences were as follows: GPx-1 (forward): AGTTCGGACA TCAGGAGAATGGCA, GPx-1 (reverse): TC ACCATTCACCTCGCACTTCTCA [20], $\beta$-actin (forward): AAGTCCCTCACCCTCCC AAAAG and $\beta$-actin (reverse): AAGCAATG CTGTCACCTTCCC [43]. The realtime PCR conditions included initial $95^{\circ} \mathrm{C}$ for $2 \mathrm{~min}$. followed by 35 cycles of $95^{\circ} \mathrm{C}$ for $5 \mathrm{sec}$. and $60^{\circ} \mathrm{C}$ for $30 \mathrm{sec}$. Melting curve analysis was done to ensure specificity.

Relative expression of GPx-1 was calculated as $\Delta \mathrm{Ct}$, measured by subtracting the $\mathrm{Ct}$ of the target GPx-1 from that of the $\beta$-actin. Lower $\Delta \mathrm{Ct}$ values indicated higher expression level of GPx-1. Fold expression changes were calculated using the equation $2-\Delta \Delta$ ct [29]. This was done using the web-based software of SABioscience; Single or Multi-Gene
qPCR Assays of the RT2 Profiler PCR Array Data Analysis Version 3.5. This software calculates the average fold change with $95 \%$ confidence interval $(95 \% \mathrm{CI}) .95 \%$ CI for the Fold Change value is calculated according to the following equation:

$95 \% \mathrm{CI}=\left(\mathrm{FC}-1.96 * \sigma_{\mathrm{FC}}, \mathrm{FC}+1.96 * \sigma_{\mathrm{FC}}\right)$ Where:

$\sigma_{\mathrm{FC}}=\mathrm{FC} * \ln 2 * \operatorname{sqrt}\left(\sigma_{\mathrm{x}}{ }^{2} / \mathrm{n}_{\mathrm{x}}+\sigma_{\mathrm{y}}{ }^{2} / \mathrm{n}_{\mathrm{y}}\right)$.

FC:fold change

$\sigma_{\mathrm{x}}$ : standard deviation of $\Delta \mathrm{Ct}$ of test group

$\sigma_{\mathrm{y}}$ : standard deviation of $\Delta \mathrm{Ct}$ of control group or the calibrator group used.

$\mathrm{n}_{\mathrm{x}}$ : number of test group.

$\mathrm{n}_{\mathrm{y}}$ : number of control group or the calibrator group.

\subsection{Statistical Analysis}

SPSS version 22 software was used for statistical analysis. Suitable statistical techniques were calculated as mean, $\pm \mathrm{SD}$. One way ANOVA \& LSD as post hoc test were used as tests of significance. Pearson correlation was done to correlate the different laboratory parameters with each other [49].

\section{Results}

\subsection{Serum ALT, AST, Total Proteins and Albumin Levels (Table 1)}

The current study showed non significant changes of Serum ALT, AST, total proteins and albumin levels in vitamin E control group compared to the control group. Moreover, it revealed significant elevation of Serum ALT and AST levels and significant reduction of serum total proteins and albumin levels in the $\mathrm{ZnO}-\mathrm{NPs}$ intoxicated group compared to the control group.

On the other hand, significant reduction of Serum ALT and AST levels and significant elevation of serum total proteins and albumin levels were found in vitamin E protected group compared to ZnO-NPs intoxicated group. However, serum total proteins and albumin levels in spite of elevation were still significantly lower than those of the control group and vitamin E control group, while serum ALT and AST levels reached non-significant levels compared to the control group and vitamin E control group.

Table 1. Liver function tests in the different study groups (Mean \pm SE).

\begin{tabular}{lllll}
\hline Parameter & Control & Vitamin E & ZnO-NPs & Vitamin E + ZnO-NPs \\
\hline ALT (U/L) & $23.45 \pm 0.34$ & $23.83 \pm 0.44^{\mathrm{a}}$ & $101.29 \pm 0.52^{\mathrm{b}^{* *}}$ & $24.06 \pm 0.36^{\mathrm{a}^{* * \#}}$ \\
AST (U/L) & $46.28 \pm 0.36$ & $46.35 \pm 0.38^{\mathrm{a}}$ & $113.82 \pm 0.24^{\mathrm{b}^{* *}}$ & $47.11 \pm 0.33^{\mathrm{a}^{* * \#}}$ \\
Total protein(g/d) & $6.90 \pm 0.13$ & $7.06 \pm 0.11^{\mathrm{a}}$ & $3.51 \pm 0.17^{\mathrm{b}^{* *}}$ & $6.19 \pm 0.13^{\mathrm{b}^{* * *}}$ \\
Albumin (g/dl) & $3.40 \pm 0.11$ & $3.36 \pm 0.18^{\mathrm{a}}$ & $2.36 \pm 0.11^{\mathrm{b}^{* *}}$ & $3.10 \pm 0.13^{\mathrm{b}}$ \\
\hline
\end{tabular}

${ }^{\mathrm{a}} \mathrm{p}>0.5,{ }^{\mathrm{b}} \mathrm{p}<0.001$ compared to control group.

${ }^{*} \mathrm{p}>0.5,{ }^{* *} \mathrm{p}<0.001,{ }^{* * *} \mathrm{p}=0.001$ compared to vitamin $\mathrm{E}$ control group.

$\# p<0.001$ compared to $\mathrm{ZnO}-\mathrm{NPs}$ intoxicated group. 


\subsection{Liver Tissue MDA Level, GSH Level and GPX Activity (Table 2)}

Vitamin E administration alone caused non significant decrease of liver MDA level and significant improvement of the antioxidant status of the liver indicated by the significant increase of GSH level and GPx activity compared to the control group.

On the other hand, there was significant increase of MDA level and significant decrease of GSH level and GPx activity in the ZnO-NPs intoxicated group compared to the control group.

Coadministration of vitamin $\mathrm{E}$ with $\mathrm{ZnO}-\mathrm{NPs}$ caused significant decrease of MDA level and significant increase of GSH level and GPx activity compared to ZnO-NPs administration alone. However, MDA level was still significantly higher and the GSH level was still significantly lower than in the control group. On the other hand, GPx activity was significantly better than in the control group.

Table 2. Liver MDA, GSH and GPx in the different study groups (Mean \pm SE).

\begin{tabular}{|c|c|c|c|c|}
\hline Parameter & Control & Vitamin E & ZnO-NPs & Vitamin E + ZnO-NPs \\
\hline MDA (nmol/g) & $30.81 \pm 0.39$ & $30.74 \pm 0.51^{a}$ & $51.71 \pm 0.52^{\mathrm{b}^{* *}}$ & $34.90 \pm 0.42^{\mathrm{b}^{* * \#}}$ \\
\hline GSH (nmol/g) & $35.17 \pm 0.34$ & $43.08 \pm 0.58^{b}$ & $10.84 \pm 0.25^{\mathrm{b}^{* *}}$ & $33.73 \pm 0.47^{\mathrm{b**} \#}$ \\
\hline GPx (U/mg protein) & $0.354 \pm 0.11$ & $0.445 \pm 0.15^{b}$ & $0.025 \pm 0.13^{\mathrm{b}^{* *}}$ & $0.384 \pm 0.11^{\mathrm{c} * * \#}$ \\
\hline
\end{tabular}

${ }^{\mathrm{a}} \mathrm{p}>0.5,{ }^{\mathrm{b}} \mathrm{p}<0.001,{ }^{\mathrm{c}} \mathrm{p}<0.01$ compared to control group.

$* * \mathrm{p}<0.001$ compared to vitamin E control group.

\# $<<0.001$ compared to $\mathrm{ZnO}-\mathrm{NPs}$ intoxicated group.

\subsection{Liver Tissue GPx-1 mRNA Expression Levels: (Figures $1,2,3)$}

Vitamin E administration caused significant fold increase of liver tissue GPx-1 expression with a fold change of 37.27 with $95 \%$ CI of (19.85- 54.69) compared to the control.

Analysis of the fold change in the liver tissue expression level of GPx-1 in ZnO-NPs intoxicated group compared to control group revealed significant fold decrease of 5.9 (fold change of 0.17 and $95 \%$ CI of [0.09, $0.25])$.

Coadminstration of vitamin $\mathrm{E}$ with $\mathrm{ZnO}-\mathrm{NPs}$ caused significant fold increase of GPx-1 gene expression compared to $\mathrm{ZnO}-\mathrm{NPs}$ intoxicated group with fold change of 36.25 and $95 \%$ CI of $(28.95,43.55)$. Moreover, GPx-1 gene expression in vitamin $\mathrm{E}$ protected group showed significant fold increase of 6.15 with $95 \%$ CI of (3.28, 9.02) compared to control group. However, GPx-1 gene expression in vitamin $\mathrm{E}$ protected group showed significant fold decrease of 6.06 (fold change of 0.16 and $95 \%$ CI of [0.13-0.19]) compared to vitamin E control group.

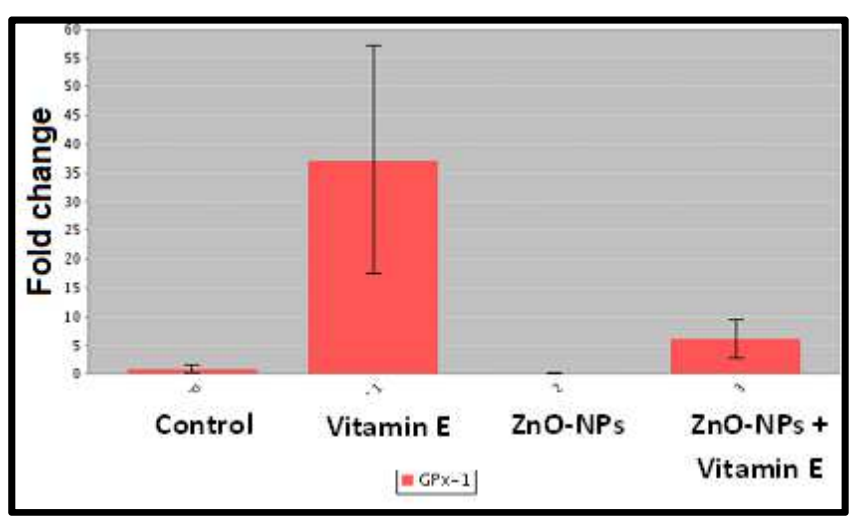

Figure 1. Average fold change of GPx-1 mRNA expression (with 95\% CI) in different study groups compared to the control group.

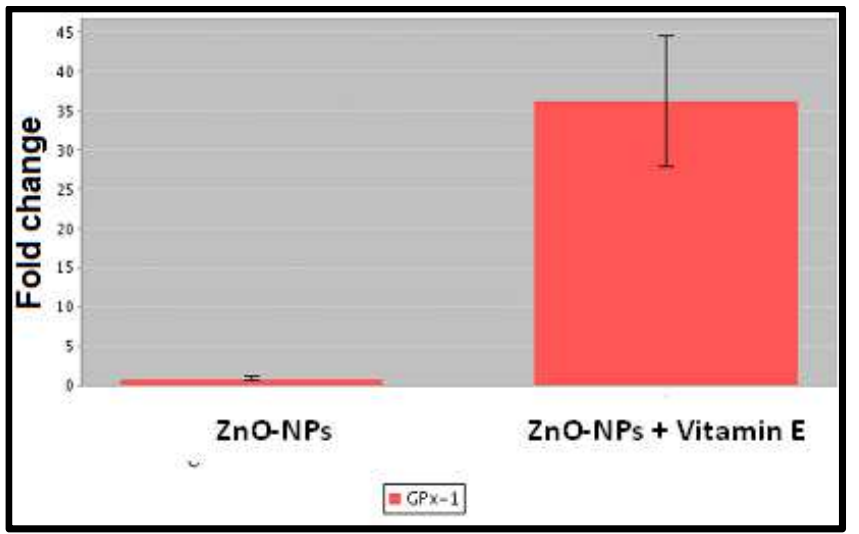

Figure 2. Average fold change of GPx-1 mRNA expression (with 95\% CI) in vitamin E protected, $\mathrm{ZnO}-\mathrm{NPs}$ intoxicated group compared to the $\mathrm{ZnO}-\mathrm{NPS}$ intoxicated group

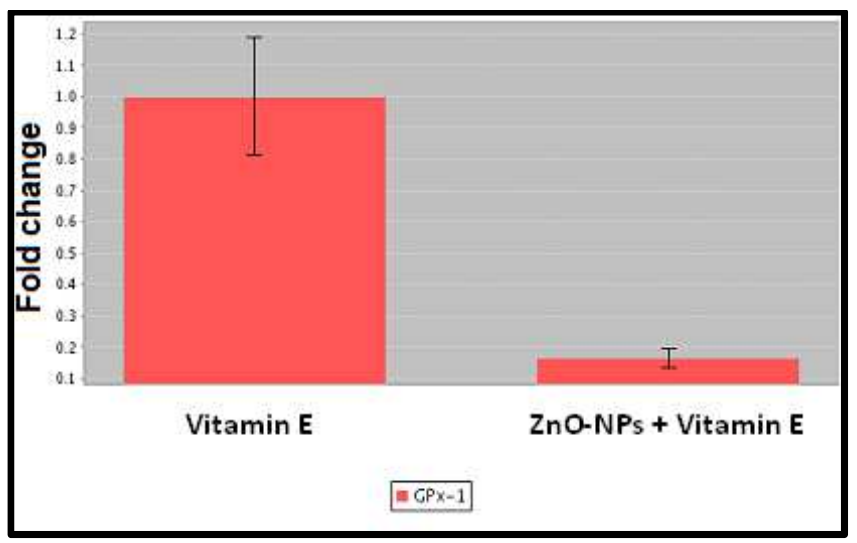

Figure 3. Average fold change of GPx-1 mRNA expression (with 95\% CI) in vitamin E protected, $\mathrm{ZnO}$-NPs intoxicated group compared to the vitamin $E$ control group.

\subsection{Serum TNF- $\alpha$ Level (Table 3)}

There was significant increase of Serum TNF- $\alpha$ level in the $\mathrm{ZnO}-\mathrm{NPs}$ intoxicated group compared to the control group. Coadminstration of vitamin $\mathrm{E}$ with $\mathrm{ZnO}-\mathrm{NPs}$ caused 
significant decrease of Serum TNF- $\alpha$ level and compared to $\mathrm{ZnO}-\mathrm{NPs}$ administration alone. However this change did not reach a non-significant level compared to control group.
Vitamin E administration alone caused non significant decrease of Serum TNF- $\alpha$ level compared to the control group.

Table 3. Serum TNF- $\alpha$ level in Control, Vitamin E control, ZnO-NPs intoxicated, and Vitamin E protected groups (Mean \pm SE).

\begin{tabular}{lllll}
\hline Parameter & Control & Vitamin E & ZnO-NPs & Vitamin E+ZnO-NPs \\
\hline TNF alpha $(\mathrm{Pg} / \mathrm{ml})$ & $9.85 \pm 0.19$ & $9.65 \pm 0.32^{\mathrm{a}}$ & $37.86 \pm 0.28^{\mathrm{b}^{* *}}$ & $13.21 \pm 0.51^{\mathrm{b}^{* * \#}}$ \\
\hline
\end{tabular}

${ }^{\mathrm{a}} \mathrm{p}>0.5,{ }^{\mathrm{b}} \mathrm{p}<0.001$ compared to control group.

$* * \mathrm{p}<0.001$ compared to vitamin E control group.

\# $\mathrm{p}<0.001$ compared to $\mathrm{ZnO}-\mathrm{NPs}$ intoxicated group.

\subsection{Correlation of Serum ALT, AST, Total Protein and Albumin Levels with Oxidative Stress (Table 4)}

Serum ALT and AST levels showed a positive significant correlation with liver MDA level and a negative significant correlation with liver GSH level, GPx activity and GPx-1 mRNA. While serum total protein and albumin levels showed a a negative significant correlation with liver MDA level and a positive significant correlation with liver GSH level, GPx activity and GPx-1 mRNA.

Table 4. Correlation of Liver function tests with oxidative stress.

\begin{tabular}{llllll}
\hline Parameter & & MDA & GSH & GPx & GPx-1 mRNA \\
\hline ALT & r & $0.98^{*}$ & $-0.95^{*}$ & $-0.98^{*}$ & $-0.76^{*}$ \\
AST & r & $0.98^{*}$ & $-0.96^{*}$ & $-0.98^{*}$ & $-0.77^{*}$ \\
Total protein & r & $0.99 *$ & $0.97^{*}$ & $0.96^{*}$ & $0.77^{*}$ \\
Albumin & r & $0.94^{*}$ & $0.91^{*}$ & $0.88^{*}$ & $0.66^{* *}$ \\
\hline
\end{tabular}

$* \mathrm{P}<0.001 * * \mathrm{P}<0.01$

\subsection{Correlation of Liver GPX-1 $m R N A$ with Liver MDA and GSH Levels and GPx Activity}

Liver GPx-1 mRNA level showed negative significant correlation with liver MDA level $(\mathrm{r}=-0.75)$ and positive significant correlation with liver GSH level $(r=0.88)$ and liver GPx activity $(\mathrm{r}=0.87)(\mathrm{p}<0.001)$.

\subsection{Correlation of Serum TNF- $\alpha$ Level with Liver Damage and Oxidative Stress}

Serum TNF- $\alpha$ level showed positive significant correlation with AST $(r=0.99)$, ALT $(r=0.99)$ and MDA $(r=0.94)$ levels $(p<0.001)$ and negative significant correlation with albumin $(r=-0.89)$, total protein $(r=-0.85)$, GSH level $(r=$ $0.9)$ with $\mathrm{p}<0.001$, GPx activity $(\mathrm{r}=-0.61)$ and GPx-1 mRNA level $(\mathrm{r}=-0.64)$ with $\mathrm{p}<0.01$.

\section{Discussion}

Oral administration of nano- and micro-sized $\mathrm{ZnO}$ (100 $\mathrm{nm}$ and $1 \mu \mathrm{m}$ respectively) was found to result in systemic accumulation including the liver, with higher absorption, toxic effect and tissue $\mathrm{Zn}$ concentration with the nano-sized $\mathrm{ZnO}$. Oral $\mathrm{ZnO}-\mathrm{NPs}$ administration resulted in transient histopathology of the liver that was not seen after administration of $1-\mu \mathrm{m} \mathrm{ZnO}$ particles [26]. Animal experiments indicated that liver was one of the target organs of oral exposure to 20- and 120-nm ZnO-NPs [54].

It was reported that the dose of $\mathrm{ZnO}-\mathrm{NPs}$ is no longer a sole factor in evaluating the NPs toxicity. The physicochemical properties of the NPs such as size, shape, high specific surface area and its solubility may play a more important role in its toxicity [30].

The current study showed that the administration of $\mathrm{ZnO}$ NPs $\left(<100 \mathrm{~nm}\right.$ with specific Surface Area of $\left.15-25 \mathrm{~m}^{2} / \mathrm{g}\right)$ in rats in a dose of $400 \mathrm{mg} / \mathrm{kg}$ body weight for seven days induced liver damage. This is evidenced by the significant elevation of serum ALT and AST over the normal control group, implying loss of the cell membrane integrity in the liver and cellular leakage [54]. Another indicator of liver tissue damage is the significant decrease of serum total proteins and albumin compared to the normal control group. Moreover, the significant increase of MDA in the liver homogenate of the $\mathrm{ZnO}$-NPs group over the control group confirms the occurrence of liver damage, since liver MDA is used as an indicator of liver tissue damage, because it is a major reactive aldehyde that is released after membrane lipid peroxidation [37]. The effect of $\mathrm{ZnO}-\mathrm{NPs}$ on serum ALT, AST, albumin, total protein and liver MDA indicated that the liver is one of the target organs of such NPs toxicity. Similar effects of ZnO-NPs on serum ALT, AST, and MDA levels were reported $[4,34,50,58]$. Also, the significant decrease of the total serum proteins and albumin caused by $\mathrm{ZnO}-\mathrm{NPs}$ agreed with Wang et al. (2010) [57] and Al-Rasheed et al. (2012) [2].

In the current study, the cause of $\mathrm{ZnO}-\mathrm{NPs}$ induced liver damage appears to be related to oxidative stress. This is evidenced by the significant decrease of GSH level, GPx activity and GPx-1 mRNA level and the significant increase of MDA in the liver homogenate of $\mathrm{ZnO}-\mathrm{NPs}$ group compared with control group. It is further confirmed by the significant correlation of liver damage indicators (serum ALT, AST, total protein and albumin) with liver MDA level, GSH level, GPx activity and GPx-1 gene expression.

According to previous studies, ZnO-NPs toxicity occurs directly from the NPs themselves or from $\mathrm{Zn}^{+2}$ ions released either after cellular uptake and intracellular dissolution within the acidic endosomal /lysosomal compartments. This results in cytotoxicity, oxidative stress, and mitochondrial dysfunction [7, 9, 11, 53, 56]. Mansouri et al. (2015) [34] and Yang et al. (2015) [33], reported higher Zn concentration in the liver tissues of rodents orally administered $\mathrm{ZnO}-\mathrm{NPs}$ and showed elevated serum AST and ALT. In addition, it was reported that liver damage could be induced by excess oral $\mathrm{Zn}$ salt [10] and oral nanoscale zinc powder [55]. Increased 
$\mathrm{Zn}$ ions were incriminated in the activation of ROS production through interaction with membrane lipids damaging the cell membrane, DNA and proteins [31].

It was reported that $\mathrm{Zn}$ at normal level possesses antioxidant ability, but become toxic at high and moderate concentrations in aquatic animals [52]. Moreover, other studies on aquatic animals reported that $\mathrm{ZnO}-\mathrm{NPs}$ at lower concentration induced both the enzymatic (as GPx activity and gene expression) and the non enzymatic (as GSH level) antioxidant defense systems. Therefore, increasing scavenging of free radicals occurred leading to decrease of MDA production, evidenced by lower MDA level in these studies. On the contrary, at higher concentration of ZnO-NPs, these antioxidant defense systems were inhibited with increase of MDA level [18, 44]. This indicated the occurrence of oxidative stress by the over accumulated free radicals which exceeded the scavenging ability of the antioxidant systems which may have been resulted from the decrease of the antioxidant defense systems. These findings were reinforced by Afifi et al. (2015) who reported that $\mathrm{ZnO}$ NPs administered in a small dose to diabetic rats, decreased the oxidative stress induced by diabetes and induced the antioxidant enzyme systems as GSH level, GPx activity and gene expression [1]. However, on using high doses of $\mathrm{ZnO}$ NPs significant decrease in GSH level and GPx activity with a significant increase in MDA in rats liver occurred as reported by Somayeh and Mohammad (2014) [50] and Mansouri et al. (2015) [34].

A previous study showed that in GPx-1 knockout mice, there was increased susceptibility to oxidative stress induced by different toxins leading to tissue damage including the liver [6]. This agrees with our finding that the decrease of liver GPx-1 mRNA expression in ZnO-NPs intoxicated rats positively correlated with the increase of serum ALT, AST and the decrease of serum total protein and albumin (liver damage). It also correlated with the increase of liver MDA and decrease liver GSH level in $\mathrm{ZnO}-\mathrm{NPs}$ intoxicated rats (oxidative stress) in our study.

The current study revealed that vitamin $\mathrm{E}$ administration resulted in significant reduction of $\mathrm{ZnO}-\mathrm{NPs}$ induced elevation of serum ALT and AST levels and significant elevation of $\mathrm{ZnO}-\mathrm{NPs}$ induced reduction of serum albumin and total protein levels. This indicated that vitamin $\mathrm{E}$ reverses the damaging effect of $\mathrm{ZnO}-\mathrm{NPs}$ on the liver. Similar effects on the serum albumin and total protein levels were demonstrated by Wang et al. (2010) [57] and AlRasheed et al. (2012) [2]. Also similar effects on serum ALT and AST were reported $[2,57,58,62]$. Furthermore, serum total proteins and albumin levels in spite of elevation were still significantly lower than those of the control group and vitamin E control group, while serum ALT and AST levels reached non-significant levels compared to the control group and vitamin $\mathrm{E}$ control group. This indicated that the hepatic cells apoptosis and damage has nearly stopped, but still the liver cell function was not regained completely.

Furthermore, according to the results of this study, vitamin $\mathrm{E}$ administration to healthy rats caused significant elevation of liver GSH level, GPx activity and GPx-1 mRNA expression compared to the control group. Also, vitamin E administration to $\mathrm{ZnO}-\mathrm{NPs}$ intoxicated rats led to significant elevation of liver GSH level, GPx activity and GPx-1 mRNA expression together with significant reduction in liver MDA compared to $\mathrm{ZnO}-\mathrm{NPs}$ intoxicated rats without vitamin $\mathrm{E}$ administration. Therefore, vitamin E protected the liver cells from the damaging effects of ROS generated by the effect of $\mathrm{ZnO}-\mathrm{NPs}$. These results are supported by the results of Khanna et al. (2015) [25] and Mansouri et al. (2015) [57] who reported that vitamin $\mathrm{E}$ as an antioxidant substance increased the level of GSH in liver, scavenged ROS, inhibited their generation and decreased the processes of lipid peroxidation and surface modification of nanoparticles and thus preventing injury to liver cells. Moreover, many studies showed that overexpression of GPx-1 can protect cells against ROS and can also inhibit hydrogen peroxide-induced apotosis in cell lines [6]. In this study, vitamin E caused increase of GPx-1 expression, which protected the liver from damage by ROS evidenced by decrease serum ALT and AST and liver MDA levels and increase serum total protein and albumin levels. Also, in many of these overexpression studies, GPx-1 activity may be 10-100 times greater than in the parent cell lines (Arthur, 2000). This agrees with this study finding that GPx-1mRNA expression positively correlates with GPx activity.

As regards serum TNF- $\alpha$ level, different studies reported its significant elevation in $\mathrm{ZnO}-\mathrm{NPs}$ intoxicated rats compared to healthy rats $[3,5,62]$. This is in agreement with the current study results indicating the inflammatory effect of ZnO-NPs. TNF- $\alpha$ is an immuno-inflammatory injurious mediator increased in response to inflammation induced by metal oxide toxicity including $\mathrm{ZnO}[13,17,47]$.

The up regulation of TNF- $\alpha$ has a principle role in proinflammatory pathways activation in various cell types [12]. It induces the production of other inflammatory cytokines including IL-6 leading to inflammatory tissue injury including the liver [24].

In this study, serum TNF- $\alpha$ level significantly correlated positively with serum ALT and AST and liver MDA levels and negatively with serum total protein and albumin levels confirming the role of the elevated serum TNF- $\alpha$ level in the pathophysiology of liver damage induced by ZnO-NPs. This is in agreement with Idriss et al. (2014) who reported that Serum level of soluble TNF- $\alpha$ (sTNF- $\alpha$ ) receptor 1 was increased and positively correlated with serum ALT and AST levels in liver disease. TNF- $\alpha$ receptors are actually membrane receptors that have been separated from activated neutrophils, mononuclear blood cells and fibroblasts and became soluble receptors that are able to bind circulating TNF- $\alpha$ and are important in regulating its activity [19]. Therefore, sTNF- $\alpha$ receptor levels may serve as a sensitive monitoring of the activity of the TNF- $\alpha$ system $[19,38]$.

Furthermore, serum TNF- $\alpha$ level showed significant positive correlation with liver MDA level and significant negative correlation with GSH level and GPx activity and GPx-1 expression. This reflects its inhibitory effect on the 
antioxidant system of the liver in ZnONPs toxicity and thus increasing liver lipid peroxidation.

TNF- $\alpha$ has been linked to oxidative stress in previous studies. It was reported to stimulate ROS production by several mechanisms including its direct toxic phenomena and its effect on mitochondrial function [21, 51]. Mitochondria were found to be major source of TNF- $\alpha$ induced ROS production $[16,17]$. TNF- $\alpha$ inhibits the activity of complex III of the mitochondrial respiratory chain, thereby inhibiting the mitochondrial electron transport increasing the production of mitochondrial ROS. Mitochondrial ROS damage the mitochondrial DNA decreasing the mitochondrial DNA copy number and causing mitochondrial dysfunction and therefore contributing to the increase of oxidative stress. However, the decrease of mitochondrial DNA copy number and complex III activity can be abolished in the presence of antioxidants [51]. However, TNF- $\alpha$ depletes both the cytosolic and mitochondrial antioxidants [36]. Therefore, TNF- $\alpha$ induces mitochondrial dysfunction via the increase of intracellular oxidative stress by depleting both cytosolic and mitochondrial antioxidants.

According to the results of this study, vitamin $\mathrm{E}$ was found to significantly alleviate $\mathrm{ZnO}-\mathrm{NPs}$ induced elevation of serum TNF- $\alpha$ level. This indicates the anti-inflammatory effect of Vitamin E, which was reported by other studies [15, 59]. Moreover, Li et al. (2012) reported that $\alpha$-tocopherol pretreatment leads to significant antagonistic effect against the TNF- $\alpha$ induced pro-inflammatory response. This occurs via modulation of the cellular response to the TNF- $\alpha$ challenge by altering the gene expression activities of some important signaling molecules [27].

\section{Conclusion and Recommendations}

In conclusion, toxic doses of $\mathrm{ZnO}-\mathrm{NPs}$ induce injurious inflammatory effect and oxidative stress by increasing ROS production and inhibiting the antioxidant system, and thus leading to liver tissue injury. Co-administration of vitamin $\mathrm{E}$ attenuates the inflammatory mediators production and alleviates the oxidative stress induced by $\mathrm{ZnO}-\mathrm{NPs}$, and thus protecting against liver tissue injury and dysfunction. It is recommended to compare the toxic effects of the various ZnO-NPs with different physical and chemical properties on the liver and other tissue organs.

\section{References}

[1] Afifi M, Almaghrabi OA and Kadasa NM (2015). Ameliorative Effect of Zinc Oxide Nanoparticles on Antioxidants and Sperm Characteristics in StreptozotocinInduced Diabetic Rat Testes. BioMed Research International, Volume 2015, Article ID 153573, 6 pages.

[2] Al-Rasheed N, Abdel Baky NA, Al-Rasheed N, Shebly W, Ahmed AM and Faddah LM (2012). Effect of vitamin E and alpha lipoic acid on nano zinc oxide induced renal cytotoxicity in rats. African Journal of pharmacy and pharmacololgy, 629 (29): 2211-2223.
[3] Al-Rasheed NM, Al-Rasheed NM, Abdel Baky NA, Faddah LM, Fatani AJ, Hasan IH and Mohamad RA (2014). Prophylactic role of $\alpha$-lipoic acid and vitamin $\mathrm{E}$ against zinc oxide nanoparticles induced metabolic and immune disorders in rat's liver. Eur Rev Med Pharmacol Sci, 18 (12): 18131828 .

[4] Al-Rasheed NM, Faddah LM, Ali HM and Abdel Baky NA (2016). Modulation of glutathione, phospholipids and lipid peroxides liver contents induced by zinc oxide Nanoparticles using natural antioxidants. Digest Journal of Nanomaterials and Biostructures, 11 (1): 303-312.

[5] Ansar S, Abudawood M, Hamed SS and Aleem MM (2016). Exposure to Zinc Oxide Nanoparticles Induces Neurotoxicity and Proinflammatory Response: Amelioration by Hesperidin. Biological Trace Element Research, First Online: 14 June 2016. In press.

[6] Arthur J R (2000). The glutathione peroxidases. Cellular and Molecular Life Sciences: CMLS, 57(13-14): 1825-1835.

[7] Bai W, Zhang Z, Tian W, He X, Ma Y, Zhao Y and Chai Z (2010). Toxicity of zinc oxide nanoparticles to zebrafish embryo: a physicochemical study of toxicity mechanism. Journal of Nanoparticle Research, 12 (5): 1645-1654.

[8] Beutler E, Duron O and Kelly BM (1963). Improved method for the determination of blood glutathione. J. Lab. Clin. Med, 61: 882-888.

[9] Chang Y-N, Zhang M, Xia L, Zhang J, and Xing G (2012). Toxic Effects and Mechanisms of $\mathrm{CuO}$ and $\mathrm{ZnO}$ Nanoparticles. Materials, 5(12): 2850-2871.

[10] Chen RH, Qin R, Wang FD, Wang JP and Lu TX (1992). The effects of oral excess zinc on the zinc level and morphology of tissues. Zhonghua Yixue Zazhi, 72: 391-393.

[11] Ciacci C, Canonico B, Bilanicov D, Fabbri R, Cortese K, Gallo G, Marcomini A, Pojana G and Canesi L (2012). Immunomodulation by different types of $\mathrm{N}$-oxides in the hemocytes of the marine bivalve Mytilus galloprovincialis. PLoS One, 7(5): e36937.

[12] D'Alessandris C, Lauro R, Presta I and Sesti G (2007). C reactive protein induces phosphorylation of insulin receptor substrate-1 on Ser307 and Ser 612 in L6 myocytes, thereby impairing the insulin signalling pathway that promotes glucose transport. Diabetologia, 50: 840-849.

[13] Faddah LM, Abdel Baky NA, Al-Rasheed NM, Al-rasheed NM, Fatani AJ and Atteya M (2012). Role of quercetin and arginine in ameliorating nano zinc oxide-induced nephrotoxicity in rats. BMC Complem Altern Med, 12: 60.

[14] Faddah LM, Abdel Baky NA, Mohamed AM, Al-Rasheed NM and Al-Rasheed NM (2013). Protective effect of quercetin and/or L-arginine against nano-zinc oxide-induced cardiotoxicity in rats. J Nanopart Res, 15: 1520.

[15] Fox ES, Brower JS, Bellezzo JM and Leingang KA (1997). Nacetylcysteine and alpha-tocopherol reverse the inflammatory response in activated rat Kupffer cells. J Immunol, 158: 54185423.

[16] Garcia-Ruiz C, Colell A, Mari M, Morales A, and FernándezCheca JC (1997). Direct effect of ceramide on the mitochondrial electron transport chain leads to generation of reactive oxygen species: role of mitochondrial glutathione. J Biol Chem, 272:11369-11377. 
[17] Goossens V, Grooten J, De Vos K and Fiers W (1995). Direct evidence for tumor necrosis factor-induced mitochondrial reactive oxygen intermediates and their involvement in cytotoxicity. Proc Natl Acad Sci U S A, 92: 8115-8119.

[18] Hao L and Chen L (2012). Oxidative stress responses in different organs of carp (Cyprinus carpio) with exposure to $\mathrm{ZnO}$ nanoparticles. Ecotoxicol. Environ. Saf, 80: 103-110.

[19] Idriss NK, Sayyed HG, Zakhary MM and Sayed S (2014). Implication of tumor necrosis factor alpha receptor 1 and hexosaminidase: relationship to pathogenesis of liver diseases. Comparative Clinical Pathology, 23 (4): 1095-1102.

[20] Iskusnykh IY, Popova TN, Agarkov AA, Pinheiro de Carvalho MÂA, and Rjevskiy SG (2013). Expression of Glutathione Peroxidase and Glutathione Reductase and Level of Free Radical Processes under Toxic Hepatitis in Rats. Journal of Toxicology. Volume 2013, Article ID 870628, 9 pages.

[21] Jamaluddin M, Wang S, Boldogh I, Tian B and Brasier AR (2007). TNF-alpha induced NF-kappaB/RelA Ser (276) phosphorylation and enhanceosome formation is mediated by an ROS-dependent PKAc pathway. Cell Signal, 19: 14191433.

[22] Kallinowski B, Haseroth K, Marinos G,Hanck C, Stremmel W, Theilmann L, Singer MV and Rossol S (1998). Induction of tumour necrosis factor (TNF) receptor type p55 and p75 in patients with chronic hepatitis $\mathrm{C}$ virus (HCV) infection. Clin Exp Immunol, 111:269-277.

[23] Kerksick C and Willoughby D (2005). The antioxidant role of glutathione and $\mathrm{N}$-acetyl-cysteine supplements and exerciseinduced oxidative stress. Journal of the International Society of Sports Nutrition, 2(2): 38-44.

[24] Kerner A, Avizohar O, Sella R, Bartha P, Zinder O, Markiewicz W, Levy Y, Brook G J and Aronson D (2005). Association Between Elevated Liver Enzymes and C-Reactive Protein Possible Hepatic Contribution to Systemic Inflammation in the Metabolic Syndrome. Arterioscler Thromb Vasc Biol, 25: 93-197.

[25] Khanna P, Ong C, Bay BH and Baeg GH (2015). An interplay of oxidative stress, inflammation and cell death. Nanomaterials, 20(5): 1163-1180.

[26] Li CH, Shen CC, Cheng YW, Huang SH, Wu CC, Kao CC, Liao JW and Kang JJ (2011). Organ bio distribution, clearance, and genotoxicity of orally administered zinc oxide nanoparticles in mice. Nanotoxicology, 6(7): 746-756.

[27] Li CJ, Li RW, Kahl S and lsasser TH (2012). Alpha-tocopherol alters transcription activities that modulates Tumor necrosis factor alpha (TNF- $\alpha$ ) induced inflammatory response in bovine cells. Gene Regulation and Systems Biology, (6): 1-14.

[28] Liu ZG and Han J (2001). Cellular responses to tumor necrosis factor. Curr Issues Mol Biol, 3: 79-90.

[29] Livak KJ and Schmittgen TD (2001). Analysis of relative gene expression data using real-time quantitative PCR and the 2(Delta Delta C (T)) Method. Methods, 25: 402-408.

[30] Lovern SB and Klaper R (2006). Daphnia magna mortality when exposed to titanium dioxide and fullerene (C60) nanoparticles. Environ Toxicol Chem, 25 (4): 1132-1137.

[31] Ma H, Williams PL and Diamond SA (2013). Diamond Ecotoxicity of manufactured $\mathrm{ZnO}$ nanoparticles. Environ.
Pollut. 172:76-85.

[32] Macdonald J, Galley HF and Webster NR (2003). Oxidative stress and gene expression in sepsis. British Journal of Anaesthesia, 90 (2): 221-232.

[33] Manke A, Wang L, and Rojanasakul Y (2013). Mechanisms of Nanoparticle- Induced oxidative stress and toxicity. Bio Med Research International, 2103(15): 650-665.

[34] Mansouri E, Khorsadi L, Orazizadeh M and Jozi Z (2015). Dose- dependent hepatotoxicity effect of zinc oxide nanoparticles. Nanomed J, 2(4): 273-282.

[35] Marí M, Morales A, Colell A, García-Ruiz C and FernándezCheca JC (2009). Mitochondrial glutathione, a key survival antioxidant. Antioxidants \& Redox Signaling, 11(11): 26852700 .

[36] Mariappan N, Soorappan RN, Haque M, Sriramula S and Francis J (2007). TNF-induced mitochondrial oxidative stress and cardiac dysfunction: restoration by superoxide dismutase mimetic Tempol. Am J Physiol Heart Circ Physiol, 293: H2726-H2737.

[37] Mironava T, Hadjrargyrou M, Simon M, Jurukovski V and Rafailovich MH (2010). Gold nanoparticles cellular toxicity and recovery effect of size concentration and exposure time. Toxicological \& Experimental chemistry, 92 (2): 391-407.

[38] Moura AS, Carmo RA, Teixeira AL, Teixeira MM and Rocha MO (2011). Soluble inflammatory markers as predictors of virological response in patients with chronic hepatitis $\mathrm{C}$ virus infection treated with interferon- $\alpha$ plus ribavirin. Memórias Do Instituto Oswaldo Cruz, 106(1): 38-43.

[39] Muller FL, Lustgarten MS, Jang Y, Richardson A, and Van Remmen H (2007). Trends in oxidative aging theories. Free Radical Biology and Medicine, 43(4): 477-503.

[40] Neuschwander-Tetri BA and Roll FJ (1990). Chemotactic activity for human PMN generated during ethanol metabolism by rat hepatocytes: role of glutathione and glutathione peroxidase. Biochem Biophys Res Commun, 167: $1170-1176$.

[41] Ohkawa H, Ohishi W and Yagi K (1979). Assay for lipid peroxides in animal tissues by thiobarbituric acid reaction. Anal. Biochem, 95(2): 351-8.

[42] Paglia DE and Valentine WN (1967). Studies on the quantitative and qualitative characterization of erythrocyte glutathione peroxidase. J. Lab. Clin. Med, 70: 158-169.

[43] Peinnequin A, Mouret C, Birot O, Alonso A, Mathieu J, Clarençon D, Agay D, Chancerelle Y and Multon E (2004). Rat pro-inflammatory cytokine and cytokine related mRNA quantification by real-time polymerase chain reaction using SYBR green. BMC Immunology, 5: 3-13.

[44] Saddick S, Afifi M and Abu Zinadaa OA (2015). Effect of Zinc nanoparticles on oxidative stress-related genes and antioxidant enzymes activity in the brain of Oreochromis niloticus and Tilapia zillii. Saudi Journal of Biological Sciences. Available online 18 November 2015 In Press.

[45] Sahu D, Kannan GM and Vijayaraghavan R (2014). Size dependant effect of zinc oxide on toxicity and inflammatory potential of human monocyte. J Toxicol Environ Health A, 77(4): 177-191. 
[46] Saptarshi SR, Duschl A and Lopata AL (2015). Biological reactivity of zinc oxide nanoparticles with mammalian test systems. Nanomedicine, 10(13): 2075 - 2092.

[47] Sayes CM, Reed KL and Warheit DB (2007). Assessing toxicity of fine and nanoparticles: comparing in vitro measurements to in vivo pulmonary toxicity profiles, Toxicol. Sci 97: 163-180.

[48] Sharma V, Anderson D and Dhawan A (2012). Zinc oxide nanoparticles induce oxidative DNA damage and ROStriggered mitochondria mediated apoptosis in human liver cells (HepG2). Apoptosis. 17(8): 852-870.

[49] Snedecor GW and Cochran WG (1982). Statistical method. $7^{\text {th }}$ ed, Iowa state university press, Ame Iowa, USA.

[50] Somayeh B and Mohammad F (2014). Vitamin C can reduce toxic effect of nano zinc oxide. Int. J. Biological Sci, 3(3): 6570 .

[51] Suematsu N, Tsutsui H, Wen J, Kang D, Ikeuchi M, Ide T, Hayashidani S, Shiomi T, Kubota T, Hamasaki N and Takeshita A (2003). Damage and Dysfunction in Cardiac Myocytes Oxidative Stress Mediates Tumor Necrosis Factor-a-Induced Mitochondrial DNA Circulation, 107: 1418-1423.

[52] Trevisan R, Flesch S, Mattos J, Milani MR, Bainy AC and Dafre AL (2014). Zinc causes acute impairment of glutathione metabolism followed by coordinated antioxidant defenses amplification in gills of brown mussels Perna perna. Comp. Biochem. Physiol. C, 159: 22-30.

[53] Vandebriel RJ and De Jong WH (2012). A review of mammalian toxicity of $\mathrm{ZnO}$ nanoparticles. Nanotechnology, Science and Applications, 5: 61-71.

[54] Wang B, Feng WY, Wang M, Wang TC, Gu YQ, Zhu MT, Ouyang H, Shi JW, Zhang F, Zhao YL, Chai ZF, Wang HF and Wang $J$ (2008). Acute toxicological impact of nano and submicro-scaled zinc oxide powder on healthy adult mice. J
Nanopart Res, 10: 263-276.

[55] Wang B, Feng WY, Wang TC, Jia G, Wang M, Shi JW, Zhang F, Zhao YL and Chai ZF (2006). Acute toxicity of nano- and micro-scale zinc powder in healthy adult mice. Toxicol Lett, 161 (2): 115-23.

[56] Wang B, Zhang Y, Mao Z, Yu D and Gao C (2014). Toxicity of $\mathrm{ZnO}$ nanoparticles to macrophages due to cell uptake and intracellular release of zinc ions. J Nanosci Nanotechnol, 14 (8): 5688-5696.

[57] Wang L, Wang L, Ding W and Zhang F (2010). Acute Toxicity of ferric oxide and zinc oxide Nanoparticles in Rats. Journal of Nanoscience and Nanotechnology, 10 (12): 8617-8624.

[58] Yang X, Shao H, Liu W, Gu W, Shu X, Mo Y, Chen X, Zhang $Q$ and Jiang $M$ (2015). Endoplasmic reticulum stress and oxidative stress are involved in $\mathrm{ZnO}$ nanoparticle-induced hepatotoxicity. Toxicol Lett, 2; 234 (1): 40-9.

[59] Yoshida N, Yoshikawa T, Manabe H, Terasawa Y, Kondo M, Noguchi N and Niki E (1999). Vitamin E protects against polymorphonuclear leukocyte-dependent adhesion to endothelial cells. J Leukoc Biol, 65: 757-63.

[60] Yousef JM and Mohamed AM (2015). Prophylactic role of B vitamins against bulk and zinc oxide nanoparticles toxicity induced oxidative DNA damage apoptosis in rat livers. Pak. J. Pharm. Sci, 28 (1): 175-184.

[61] Yousef JM (2014). Potential prophylactic impact of B vitamins against zinc oxide bulk and its nanoparticles induced kidney damage. Life Science Journal, 11 (8):729-738.

[62] Abdel Baky NA, Faddah LM, Al-Rasheed NM, Al-Rasheed NM, Shebali W (2013). Role of quercetin and L-arginine in alleviating zinc oxide nanoparticle hepatotoxicity in rats, Chiang Mai J. Sci, 40: 577-592. 